\title{
IMPLEMENTASI PEMBELAJARAN TEMATIK PADA SDN DI GUGUS III KECAMATAN KALASAN KABUPATEN SLEMAN DIY
}

\section{THEMATIC LEARNING IMPLEMENTATION AT SDN IN CLUSTER III KALASAN DISTRICT SLEMAN REGENCY DIY}

\author{
Bayu Purbha Sakti, Wiwik Wijayanti \\ - , Universitas Negeri Yogyakarta \\ bayumor@gmail.com,wiwikashari@gmail.com
}

\begin{abstract}
Abstrak
Penelitian ini bertujuan untuk mendeskripsikan dan memaknai implementasi pembelajaran tematik pada sekolah dasar negeri di Gugus III Kecamatan Kalasan Kabupaten Sleman Daerah Istimewa Yogyakarta. Subjek penelitian ini adalah para guru kelas I, II, dan III. Data dikumpulkan dengan teknik dokumentasi, wawancara, dan observasi serta dianalisis dengan reduksi data, penyajian data, dan penarikan kesimpulan. Hasil dari penelitian ini adalah sebagai berikut. (1) Guru sudah memahami pembelajaran tematik, tetapi masih ada 2 guru yang belum memahaminya. (2) Guru sudah merencanakan pembelajaran tematik dengan menggunakan silabus dan RPP (Rencana Pelaksanaan Pembelajaran) yang memiliki tema, tetapi masih ada 8 guru yang tidak menggunakannya. (3) Metode mengajar yang diterapkan para guru dalam implementasi pembelajaran tematik yaitu metode ceramah, kooperatif, dan peragaan. (4) Hambatan yang dihadapi adalah: (a) Minimnya pengetahuan orangtua dan siswa. (b) Lingkungan masyarakat yang tidak kondusif. (c) Keterbatasan alat peraga, buku, dan sosialisasi dinas. d) Minimnya pengetahuan guru. (5) Upaya guru mengatasi hambatan dengan: (a) Menjelaskan pembelajaran tematik kepada orangtua dan memilih media dan metode yang sesuai untuk siswa. (b) Menyelenggarakan bimbingan belajar di lingkungan masyarakat. (c) Mencari informasi di buku, internet, dan seminar supaya guru memiliki inovasi untuk mengatasi keterbatasan pembelajaran tematik. (d) Berbagi informasi dengan guru tematik yang lain untuk menambah pengetahuan.
\end{abstract}

Kata kunci: pembelajaran tematik, implementasi pembelajaran

\begin{abstract}
The aims of this study are to describe and elucidate thematic learning implementation in state elementary schools at Cluster III Kalasan District, Sleman Regency, Yogyakarta Special Territory. The subjects of this study were teachers of classes I, II, and III. The data were collected through documentation, interview, and observation and analyzed through data reduction, data display, and drawing conclusion. The results of the study are as follows. (1) Teacher has understood thematic learning but extant 2 teachers that haven't understood it. (2) Teacher has plotted thematic learning by use of syllabus and RPP (Learning Implementation Plan) one that has theme but extant 8 teacher that don't utilize it. (3) The teaching methods that was implemented by teachers in thematic learning implementation were speech, cooperative, and demonstration method. (4) The constraints faced were: (a) Minimum of student, and parent knowledge. (b) Unconducive society environment. (c) Limited tools of model, books, and socialization from education office. (d) Minimum of teacher knowledge. (5) Teacher's effort solved constraints by: (a) Explaining thematic learning towards parent and choosing suitable media and method for student. (b) Performing study guidance in society environment. (c) Finding information in books, internet, and seminar to solve limited of thematic learning. (d) Sharing information with another thematic teacher to increase knowledge.
\end{abstract}

Keywords: thematic learning, learning implementation 


\section{Pendahuluan}

Berdasarkan Peraturan Pemerintah Republik Indonesia Nomor 19 Tahun 2005 Pasal 60 tentang Standar Nasional Pendidikan disebutkan bahwa pemerintah telah menyusun rencana kerja tahunan bidang pendidikan dengan memprioritaskan program wajib belajar, peningkatan angka partisipasi pendidikan untuk jenjang pendidikan menengah dan tinggi, penuntasan pemberantasan buta aksara, penjaminan mutu pada satuan pendidikan baik yang diselenggarakan oleh pemerintah maupun masyarakat dan penjaminan mutu pendidikan nasional.

Program Wajib Belajar mewajibkan setiap Warga Negara Indonesia untuk bersekolah selama 9 tahun pada jenjang pendidikan dasar yaitu dari tingkat kelas 1 sekolah dasar hingga kelas 9 sekolah menengah pertama (Depdiknas, 2011). Program Wajib Belajar yang bermula dari program Wajib Belajar 6 tahun diperpanjang menjadi program Wajib Belajar 9 tahun. Program itu mengharuskan setiap murid tetap bersekolah hingga lulus dari sekolah menengah pertama (atau kelas 9).

Mendikbud mengatakan akan memperluas akses semua anak bangsa dalam dunia pendidikan melalui program Wajib Belajar 9 tahun, BOS, dan bantuan untuk siswa kurang mampu serta program Wajib Belajar 12 tahun yang dimulai tahun 2013 (Nuh, 4 Desember 2012).). Program Wajib Belajar 12 tahun dicanangkan sebagai wujud komitmen kesinambungan dengan wajib belajar sembilan tahun yang telah dicanangkan pada era Presiden Soeharto (Nuh, 25 Juni 2013). Program Wajib Belajar 12 tahun itu juga disebut sebagai program Pendidikan Menengah Universal (PMU). Program itu mengharuskan setiap murid tetap bersekolah hingga lulus dari sekolah menengah umum (atau kelas 12).

Berdasarkan Peraturan Pemerintah Republik Indonesia Nomor 28 Tahun 1990 pendidikan dasar disebutkan bahwa pendidikan dasar merupakan pendidikan sembilan tahun, terdiri atas program pendidikan enam tahun di sekolah dasar dan program pendidikan tiga tahun di sekolah lanjutan tingkat pertama. Target program itu adalah bahwa setiap anak usia 6 hingga 15 tahun semuanya sudah akan duduk di sekolah sampai sekolah menengah pertama.

Indonesia telah mengalami kemajuan yang sangat besar dalam menentukan anak-anak yang duduk di bangku sekolah dasar untuk mendapatkan pendidikan. Pendidikan untuk anak-anak di sekolah dasar itu terbukti telah mampu memberantas buta aksara. Pemerintah meratifikasi Program UNESCO Education for All 2015 yang ditandatangani di Dakar tahun 2000 (Unesco, 2013). Hal tersebut membuat Indonesia berkewajiban mengurangi tingkat buta aksara 5\% dan memberikan pendidikan dasar bagi semua anak-anak sebelum tahun 2015.

Belajar secara integrasi yang dilakukan anak usia sekolah dasar adalah belajar mengenai satu tema atau pokok pikiran. Pembelajaran tersebut selama ini dikenal dengan pembelajaran tematik. Pembelajaran tematik telah dicanangkan dan dilaksanakan oleh pemerintah sejak diberlakukannya Kurikulum Berbasis Kompetensi pada tahun 2004.

Berdasarkan Undang-Undang Republik Indonesia nomor 20 tahun 2003 tentang Sistem Pendidikan Nasional Pasal 37 Ayat 1 disebutkan bahwa kurikulum pendidikan dasar dan menengah wajib memuat: pendidikan agama, pendidikan kewarganegaraan, bahasa, matematika, ilmu pengetahuan alam, ilmu pengetahuan sosial, seni dan budaya, pendidikan jasmani dan olahraga, keterampilan/kejuruan, serta muatan lokal. Sejak diberlakukannya KBK (Kurikulum Berbasis Kompetensi) maka pembelajaran yang berlangsung di kelas I dan II harus dilaksanakan secara tematik. Bahkan setelah diresmikannya KTSP (Kurikulum Tingkat Satuan Pendidikan) maka pembelajaran tematik harus sudah dilaksanakan mulai dari kelas I, II, dan III.

Pada tahun 2013 ini Kementerian Pendidikan dan Kebudayaan merencanakan kurikulum baru dengan nama kurikulum 2013. Kurikulum SD/MI menggunakan pendekatan pembelajaran tematik integratif dari kelas I sampai kelas VI (Kementerian Pendidikan dan Kebudayaan, 2013, p.137).

Berdasarkan hasil prasurvei di beberapa sekolah dasar negeri di Kecamatan Kalasan yaitu SDN Karangnongko I, SDN Pakem, SDN Purwobinangun, dan SDN Sidorejo maka diperoleh informasi tentang pembelajaran tematik. Dari keempat sekolah dasar tersebut terdapat sekolah dasar yang sudah dan belum mengimplementasikan pembelajaran tematik. Keempat sekolah dasar tersebut dipilih secara acak dalam kegiatan prasurvei implementasi pembelajaran tematik.

Berdasarkan hasil prasurvei di UPTD (Unit Pelayanan Terpadu Daerah) Kecamatan Kalasan maka didapatkan sekolah dasar yang telah mengimplementasikan pembelajaran te- 
matik di Gugus III. Sekolah dasar tersebut telah mengimplementasikan pembelajaran tematik dan memiliki guru dengan prestasi bertaraf nasional. Pembelajaran tematik sudah dilaksanakan di SDN 1 Kalasan yang terdapat di gugus III Kecamatan Kalasan. Sekolah ini merupakan rujukan dari kepala UPTD Kecamatan Kalasan.

Selain itu, didapatkan hasil prasurvei yang dilakukan di gugus lainnya. Pembelajaran tematik masih setengah-setengah dilaksanakan di SDN Pakem yang terdapat di Gugus II Kecamatan Kalasan karena sedikitnya pemahaman para guru. Silabus dan RPP (Rencana Pelaksanaan Pembelajaran) tematik sudah lengkap namun belum dikerjakan secara lengkap. Para guru belum menguasai proses penyatuan tema dalam penerapan pembelajaran tematik. Guru terbebani dengan adanya tugas tambahan seperti tugas menyusun administrasi, menyusun perencanaan manajemen keuangan, dan sebagainya sehingga guru menjadi kurang fokus dalam mengajar. Para guru merasa perlu adanya pelatihan pembelajaran tematik. Oleh karena itu mereka belajar tentang pembelajaran tematik secara mandiri. Belum adanya pelatihan, seminar, dan workshop bagi guru dari dinas pendidikan tentang implementasi pembelajaran tematik sangat disayangkan para guru.

Pembelajaran tematik belum dilaksanakan di SDN Sidorejo yang terdapat di Gugus I Kecamatan Kalasan dan para guru merasa sangat kesulitan dalam menerapkannya. Penjadwalan pembelajaran masih disusun terpisah secara mata pelajaran dan bukan secara tematik. Kesalahan perencanaan penjadwalan itu menyulitkan guru untuk merancang dan menyusun silabus dan RPP tematik terutama dalam menentukan standar kompetensi dan kompetensi dasar. Pada pelaksanaannya masih terpisah secara mata pelajaran. Pelaksanaan pembelajaran di kelas I, II, dan III belum dilaksanakan secara tematik. Cara penyampaian materi pembelajaran tematik yang disampaikan dan diimplementasikan ke siswa belum mengacu ke tema karena pergantian antar mata pelajaran ditandai dengan mengisyaratkan kode warna buku. Belum adanya pelatihan, seminar, dan workshop bagi guru dari dinas pendidikan tentang implementasi pembelajaran tematik sangat membingungkan para guru.

Pembelajaran tematik sudah dilaksanakan di SDN Purwobinangun yang terdapat di Gugus IV Kecamatan Kalasan. Para guru terbiasa menerapkan pembelajaran tematik dari silabus dan RPP tematik. Pembelajaran tematik dibahas di 5 mata pelajaran yaitu Matematika, PKn, Bahasa Indonesia, IPA, dan IPS. Para guru merasa kesulitan dalam menyusun jadwal mata pelajaran di kelas I, II, dan III secara tematik. Namun para guru menginginkan adanya sosialisasi dan publikasi dari dinas pendidikan terkait implementasi pembelajaran tematik yang belum diselenggarakan.

Pembelajaran tematik belum dilaksanakan di SDN Karangnongko I yang terdapat di Gugus V Kecamatan Kalasan. Minimnya wawasan, pemahaman, dan pengetahuan para guru sangat memengaruhi terhadap pelaksanaan pembelajaran tematik. Para guru merasa kesulitan dalam menyinkronkan mata pelajaran untuk ditematikkan. Pembelajaran tematik dibahas di 3 mata pelajaran yaitu Matematika, Bahasa Indonesia, dan IPA. Penggunaan 3 mata pelajaran itu dalam pembelajaran tematik dikarenakan kesulitan guru dalam menyinkronkan kekompleksan tema dan terbatasnya waktu jam mengajar 1 tema maksimal 2 minggu. Para guru merasa kesulitan dalam menyinkronkan mata pelajaran olahraga dengan matematika untuk pembelajaran tematik. Peran guru dalam membahas pembelajaran tematik dirasa kurang maksimal dan masih memerlukan referensi ahli terkait. Belum adanya pelatihan, seminar, dan workshop bagi guru dari dinas pendidikan tentang implementasi pembelajaran tematik tentunya menyulitkan para guru dari SDN Karangnongko I.

Berdasarkan hasil paparan prasurvei tersebut maka penelitian implementasi pembelajaran tematik dilakukan di sekolah dasar negeri yang terdapat di Gugus III Kecamatan Kalasan Kabupaten Sleman Daerah Istimewa Yogyakarta. Gugus III dipilih di dalam penelitian ini selain terdekat dengan kantor UPTD juga karena sekolah dasar negeri yang terdapat di dalam Gugus III merupakan sekolah dasar negeri yang memiliki koordinasi pertemuan dan kerja sama antarguru kelas dalam merencanakan dan melaksanakan kegiatan pembelajaran.

Penelitian ini difokuskan pada implementasi pembelajaran tematik yang dilakukan guru kelas I, II, dan III sekolah dasar negeri di Gugus III Kecamatan Kalasan Kabupaten Sleman Daerah Istimewa Yogyakarta. Tujuan penelitian ini adalah untuk mendeskripsikan dan memaknai implementasi pembelajaran tematik yang dilakukan guru kelas I, II, dan III pada sekolah dasar negeri di Gugus III Kecamatan Kalasan Kabupaten Sleman Daerah Istimewa Yogyakarta. 
Manfaat penelitian ini secara teoritis memberikan sumbangan pemikiran ilmiah untuk perkembangan pendidikan pada sekolah dasar negeri di Gugus III Kecamatan Kalasan dalam menerapkan pembelajaran tematik. Manfaat penelitian ini secara praktis sebagai dorongan untuk mendesain pembelajaran tematik yang kreatif dan inovatif sehingga mampu meningkatkan hasil belajar peserta didik walaupun dalam kondisi yang tidak memadai untuk melakukan proses belajar mengajar

\section{Metode}

Jenis Penelitian

Pendekatan penelitian ini adalah penelitian kualitatif. Deskripsi penelitian ini adalah cara guru di kelas I, II, dan III SDN Gugus III Kecamatan Kalasan dalam berpikir dan berperilaku dalam kegiatan implementasi pembelajaran tematik serta dideskripsikan sebagaimana persepsi mereka.

\section{Tempat dan Waktu Penelitian}

Penelitian ini dilaksanakan di SDN Kalasan 1, SDN Kalasan Baru, SDN Bogem 1, SDN Bendungan, dan SDN Kowangbinangun. Waktu penelitian ini dilaksanakan pada bulan Maret tahun 2013 sampai dengan bulan Mei Tahun 2013

Subjek atau Responden

Subjek penelitian ini adalah guru kelas I, II, dan III. Penelitian dengan subjek guru kelas I, II, dan III adalah untuk mengetahui cara guru merencanakan dan menerapkan pembelajaran tematik. Kriteria pemilihan subjek penelitian berdasarkan guru yang mengajar di kelas I, II, dan III sekolah dasar negeri pada Gugus III Kecamatan Kalasan. Pemilihan guru di kelas I, II, dan III disebabkan pembelajaran tematik yang dijelaskan dalam KTSP (Kurikulum Tingkat Satuan Pendidikan) berlangsung pada kelas I, II, dan III.

Teknik dan Instrumen Pengumpulan Data

Teknik pengumpulan data yang digunakan dalam penelitian ini adalah teknik observasi, wawancara, dan dokumentasi. Instrumen pengumpulan data yang digunakan dalam penelitian ini adalah pedoman observasi, wawancara, dan dokumentasi.

Analisis Induktif

Analisis data yang dibangun dalam penelitian ini menggunakan model yang dikem- bangkan Miles \& Huberman (2009, pp.16-21) yaitu Analysis Interactive Model. Analisis data dalam penelitian ini dilakukan dengan pengumpulan data (data collection) terbagi dalam tiga tahap, yaitu: penyajian data (data display), reduksi data (data reduction), dan verifikasi data (data verifying).

\section{Hasil Penelitian dan Pembahasan}

Kebiasaan para guru dalam berpikir dan berperilaku dalam kegiatan implementasi pembelajaran tematik berada pada sekolah masing-masing yang terletak di Gugus III dimana gugus tersebut adalah gugus yang terdekat dengan UPTD (Unit Pelayanan Terpadu Daerah) dan kantor Kecamatan Kalasan yang berlokasi pada 7.77 ' Lintang Selatan dan 110.46' Bujur Timur. Selain itu letak sekolah mereka berada di dekat Jalan Solo. SDN Kalasan 1 berada di utara Jalan Yogya-Solo Km 13,5 dan berada di selatan kantor Kecamatan Kalasan. SDN Bendungan berada di selatan Jalan Yogya-Solo Km 13,5 dan berada $300 \mathrm{~m}$ selatan kantor Kecamatan Kalasan. SDN Kalasan Baru berada di utara Jalan Yogya-Solo Km 14 dan berada di barat SMPN 1 Kalasan. SDN Kowangbinangun berada 200 m di selatan Jalan Yogya-Solo Km 14,8 dan berada di selatan SMK Immanuel Kalasan. SDN Bogem 1 berada $100 \mathrm{~m}$ di selatan Jalan Yogya-Solo Km 15 dan berada di selatan SMAN 1 Kalasan.

Di Gugus III Kecamatan Kalasan terdapat guru tematik yang baru beberapa tahun mengajar mau sudah lama mengajar bahkan ada guru yang yang berstatus tidak tetap seperti guru WS. Dalam penelitian ini, guru UK diketahui sebagai guru PNS sedangkan guru WS sebagai guru GTT (Guru Tidak Tetap). Kedua guru tersebut sama-sama memahami pembelajaran tematik. Jumlah status guru GTT tematik di SDN Kalasan 1 terdapat 1 orang. Jumlah status guru GTT tematik di SDN Kalasan Baru terdapat 2 orang. Tidak terdapat guru GTT tematik di SDN Bendungan. Jumlah status guru GTT tematik di SDN Bogem 1 terdapat 1 orang. Jumlah status guru GTT tematik di SDN Kowangbinangun terdapat 2 orang. Dari penjelasan di atas maka dibuat tabel guru tematik GTT dan PNS sebagai berikut: 
Tabel 1. Jumlah Guru Tematik GTT dan PNS per SDN

\begin{tabular}{clcc}
\hline No. & Sekolah Dasar Negeri & GTT & PNS \\
\hline 1. & SDN Kalasan 1 & 1 & 2 \\
2. & SDN Kalasan Baru & 2 & 4 \\
3. & SDN Bendungan & 0 & 3 \\
4. & SDN Bogem 1 & 1 & 2 \\
5. & SDN Kowangbinangun & 2 & 1 \\
\hline
\end{tabular}

Dari jumlah guru tematik GTT dan PNS di SDN Kalasan Baru diketahui berjumlah 2 dan 4 dikarenakan sekolah tersebut memiliki kelas paralel. Dari hasil tersebut maka jumlah guru tematik GTT di Gugus III Kecamatan Kalasan adalah 6 orang dan jumlah guru tematik PNS di Gugus III Kecamatan Kalasan adalah 12 orang. Namun jumlah guru yang diwawancarai dan diobservasi dalam penelitian ini sebanyak 15 guru. Hal tersebut disebabkan jumlah guru tematik GTT di SDN Kalasan Baru yang diteliti adalah 1 orang dan jumlah guru tematik PNS di SDN Kalasan Baru yang diteliti adalah 2 orang. Oleh karena itu, jumlah guru tematik GTT yang diteliti dalam penelitian di Gugus III Kecamatan Kalasan adalah 5 orang. Jumlah guru tematik PNS yang diteliti dalam penelitian di Gugus III Kecamatan Kalasan adalah 10 orang.

Kebiasaan para guru tematik di Gugus III Kecamatan Kalasan dalam berpikir dan berperilaku dalam kegiatan implementasi pembelajaran tematik diterapkan dengan pemahaman, perencanaan, metode mengimplementasikan, hambatan, dan upaya mengatasi hambatan dalam pembelajaran tematik. Para guru tematik di Gugus III Kecamatan Kalasan bersepakat untuk menyerahkan data perencanaan pembelajaran seperti penyusunan silabus dan RPP dalam satu perwakilan tiap sekolah masing-masing. Hal tersebut dikarenakan ada tiga guru tematik GTT yang masing-masing berasal dari tiga sekolah dasar negeri yang berbeda tidak dapat menyusun silabus dan RPP berdasarkan tema. Namun pencatatan silabus dan RPP tematik dalam penelitian ini direduksi menjadi satu contoh saja karena tema yang ditampilkan hanya satu saja. Silabus dan RPP tematik yang dipilih adalah silabus dan RPP yang berasal dari SDN Kalasan 1 karena adanya kesesuaian penyusunan silabus dan RPP untuk dijadikan bukti catatan bahkan guru UK sebagai penyusunnya juga bersedia menjadi narasumber bila terdapat pengecekkan data yang dependensi.
Para guru tematik di Gugus III Kecamatan Kalasan masih menyusun jadwal pembelajaran yang belum terjadwal secara tematik. Mereka masih membuat jadwal pelajaran di sekolah dasar secara terpisah dan terkotak-kotak dalam berbagai mata pelajaran untuk dijadikan bukti laporan yang diserahkan ke dinas pendidikan. Para guru mengakui jika mereka harus menyusun silabus dan RPP secara tematik tetapi mereka juga harus menyusun jadwal pelajaran secara terpisah tiap mata pelajaran. Dalam penelitian ini, guru UL yang berasal dari SDN Kalasan Baru bersedia menjadi narasumber bila terdapat pengecekkan data yang dependensi dengan proses penyusunan jadwal pelajaran.

Dalam memerjelas bukti yang berasal langsung dari para guru tematik di Gugus III Kecamatan Kalasan maka dibutuhkan deskripsi wawancara yang berkaitan dengan pengetahuan guru tematik mengenai pembelajaran tematik. Wawancara yang dilakukan melibatkan 15 guru tematik dari kelas I, II, dan III. Meskipun terdapat 6 guru tematik di SDN Kalasan Baru tetapi hanya 3 guru tematik kelas I, II, dan III yang diwawancarai untuk lebih mendapatkan hasil kredibilitas dan berimbang mengenai keterwakilan wawancara dengan guru tematik yang dilakukan dari 5 SDN di Gugus III Kecamatan Kalasan.

Untuk memeroleh keterangan dari pengajaran yang dilakukan para guru tematik di Gugus III Kecamatan Kalasan maka dibutuhkan deskripsi observasi yang berkaitan dengan cara mengajar guru tematik di kelas. Observasi yang dilakukan melibatkan 15 guru tematik dari kelas I, II, dan III. Meskipun terdapat 6 guru tematik di SDN Kalasan Baru tetapi hanya 3 guru tematik kelas I, II, dan III yang diamati untuk lebih mendapatkan hasil kredibilitas dan berimbang mengenai keterwakilan observasi implementasi pembelajaran tematik di kelas yang dilakukan dari 5 SDN di Gugus III Kecamatan Kalasan.

Berdasarkan hasil reduksi data maka terdapat penyajian data yang berkaitan pemahaman guru dalam implementasi pembelajaran tematik di Gugus III Kecamatan Kalasan. Terdapat hasil wawancara dengan guru UL dengan kode GTULW1 mengenai pemahaman guru dalam pembelajaran tematik sebagai berikut:

"Pembelajaran tematik ini menurut saya yang sudah saya pelajari itu adalah pembelajaran berdasarkan tema. Dalam arti bahwa pembelajaran ini meleburkan seтиa pelajaran menjadi satu lalu diambil tema- 
nya. Dalam pengambilan tema itu sebelumnya dibuat pemetaan tema terlebih dahulu. Untuk pemilihan tema, karena kemarin kita masih menggunakan KTSP (Kurikulum Tingkat Satuan Pendidikan) maka tema kita mengambilnya dari lingkungan sekitar berdasarkan kemampuan guru untuk mengembangkan tema itu. Dalam artian, kita mengembangkan tema sesuai yang ada dalam lingkungan sekolah."

Berdasarkan hasil wawancara tersebut maka guru UL dapat memahami pembelajaran tematik dengan memahami arti pembelajaran tematik dan pemilihan tema. Hasil wawancara tersebut merupakan salah satu bentuk penyajian data penelitian ini mengenai pemahaman guru dalam pembelajaran tematik. Berdasarkan hasil reduksi data maka terdapat 13 guru yang memahami pembelajaran tematik. Ketiga belas guru tersebut adalah UK, PW, LH, SS, UL, PY, MT, KY, FA, BL, WS, SP, dan DIS. Jumlah guru yang memahami pembelajaran tematik digambarkan dalam diagram sebagai berikut.

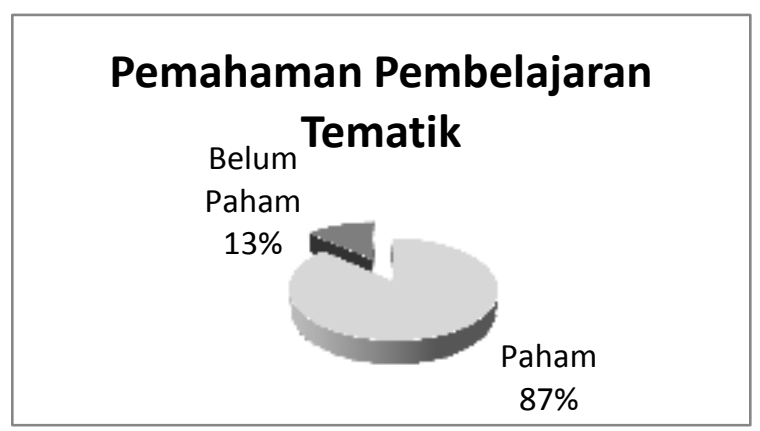

Gambar 1. Diagram Jumlah Guru yang Memahami Pembelajaran Tematik pada SDN di Gugus III Kecamatan Kalasan.

Salah satu bentuk penyajian data penelitian mengenai guru yang mampu merencanakan pembelajaran tematik di Gugus III Kecamatan Kalasan adalah hasil wawancara dengan guru WS. Terdapat hasil wawancara dengan guru WS dengan kode GTWSW2 mengenai perencanaan guru dalam pembelajaran tematik sebagai berikut:

"Untuk merencanakan pembelajaran tematik maka kita membuat dulu jaring- jaring tematik lalu mencari materi- materi pelajaran yang paling dekat dengan tema tersebut. Misalnya kita mengambil tema diri sendiri maka dalam mata pelajaran Matematika mana materi yang dapat dimasukkan ke tema tersebut. Dalam mata pelajaran IPS mana materi yang dapat dimasukkan ke tema tersebut. Kalau persiapannya dimulai dengan persiapan administratif dulu. Kita sudah menyusun seperti Program Tahunan, Program Semester, Silabus Tematik, RPP Tematik, dan Jaring-jaring Tematik."

Berdasarkan hasil reduksi data maka terdapat 7 guru yang merencanakan pembelajaran tematik dengan menggunakan silabus dan RPP. Ketujuh guru tersebut adalah UK, LH, PY, SH, BL, WS, dan DIS. Jumlah guru yang merencanakan pembelajaran tematik dengan menggunakan silabus dan RPP digambarkan dalam diagram sebagai berikut.

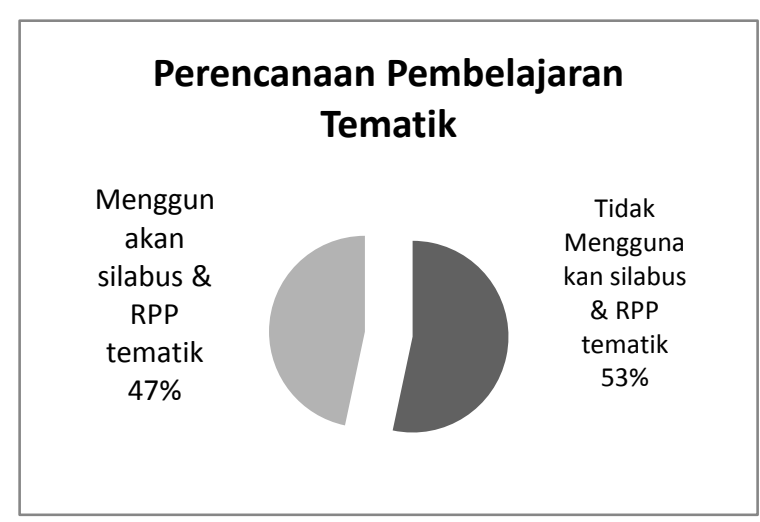

Gambar 2. Diagram Jumlah Guru yang Merencanakan Pembelajaran Tematik pada SDN di Gugus III Kecamatan Kalasan.

Salah satu bentuk penyajian data penelitian mengenai metode mengajar guru dalam mengimplementasikan pembelajaran tematik di kelas pada Gugus III Kecamatan Kalasan adalah hasil observasi dengan guru PY. Terdapat hasil observasi dengan guru PY dengan kode GTPYO1 mengenai implementasi pembelajaran tematik di kelas. Penjelasan hasil observasi dengan guru PY dikemukakan pada paragraf berikut.

Guru menjelaskan perbandingan berat ben$d a$. Guru menyuruh siswa untuk mengulangi dan mengucapkan kalimat perbandingan, "spidol ini lebih berat daripada pulpen." Para siswa lalu mengulangi kalimat perbandingan itu. Guru membandingkan berat antara spidol, pulpen, dan penggaris plastik. Guru membandingkan berat kambing lebih ringan daripada kuda. Guru membandingkan berat gelas lebih berat daripada sendok. Guru memperagakan bahwa buku tulis Rima lebih berat daripada buku tulis Tiara.

Berdasarkan hasil reduksi data maka terdapat 12 guru yang mengimplementasikan pembelajaran tematik di kelas dengan menerap- 
kan metode ceramah. Metode ceramah adalah metode yang sering diterapkan guru dalam mengimplementasikan pembelajaran tematik di kelas dan bersifat dominan. Kedua belas guru tersebut adalah PW, LH, RS, UL, PY, SH, KY, FA, BL, WS, SP, dan DIS. Selain itu, metode lain yang diterapkan adalah metode peragaan yang diterapkan seorang guru dan metode kooperatif yang diterapkan 2 guru. Jumlah guru yang menerapkan metode ceramah di Gugus III Kecamatan Kalasan digambarkan dalam diagram sebagai berikut.

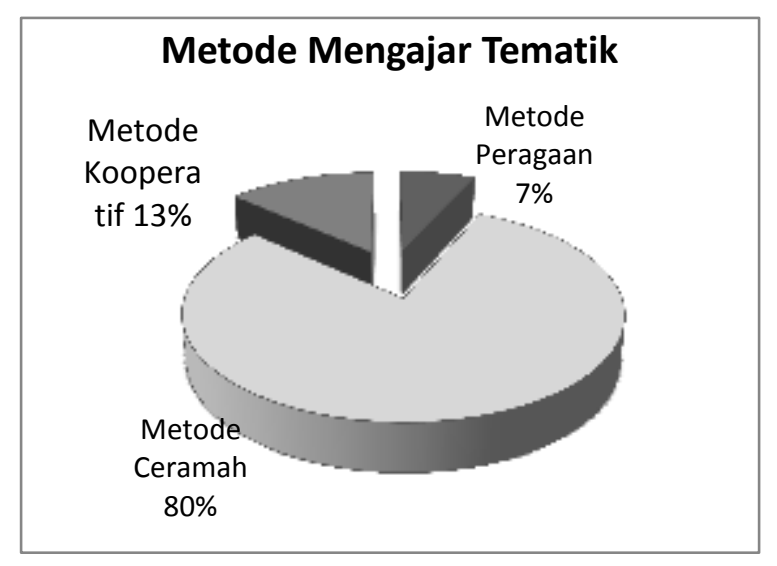

Gambar 3. Diagram Jumlah Guru yang Menerapkan Metode Mengajar Tematik pada SDN di Gugus III Kecamatan Kalasan.

Salah satu bentuk penyajian data penelitian mengenai hambatan yang dihadapi guru dalam mengimplementasikan pembelajaran tematik di Gugus III Kecamatan Kalasan adalah hasil wawancara dengan guru LH. Terdapat hasil wawancara dengan guru LH dengan kode GTLHW3 mengenai hambatan yang dihadapi guru dalam pembelajaran tematik sebagai berikut:

"Pertama adalah penghambat dari siswa. Siswa kadang-kadang kurang begitu memerhatikan dengan apa yang disampaikan. Kedua adalah penghambat dari lingkungan. Lingkungan kita kadang-kadang tidak kondusif. Ketiga adalah penghambat dari kekurangan alat peraga. Untuk sekolah kami LCD hanya ada satu dan itu dirasakan kurang. Keempat adalah penghambat dari pemilihan tema. Siswa kelas 3 masih susah untuk memahami tema yang harus diajarkan dan diinginkan guru."

Secara keseluruhan, hambatan yang dihadapi guru dalam mengimplementasikan pembelajaran tematik di Gugus III Kecamatan Kalasan adalah lingkungan masyarakat yang tidak kondusif, keterbatasan alat peraga, buku, dan sosialisasi dinas serta minimnya pengetahuan siswa, guru, dan orangtua. Berdasarkan hasil reduksi data maka terdapat 9 guru yang menjawab minimnya pengetahuan siswa sebagai hambatan yang sering dihadapi guru dalam mengimplementasikan pembelajaran tematik. Jumlah guru yang menjawab minimnya pengetahuan siswa sebagai hambatan digambarkan dalam diagram sebagai berikut.

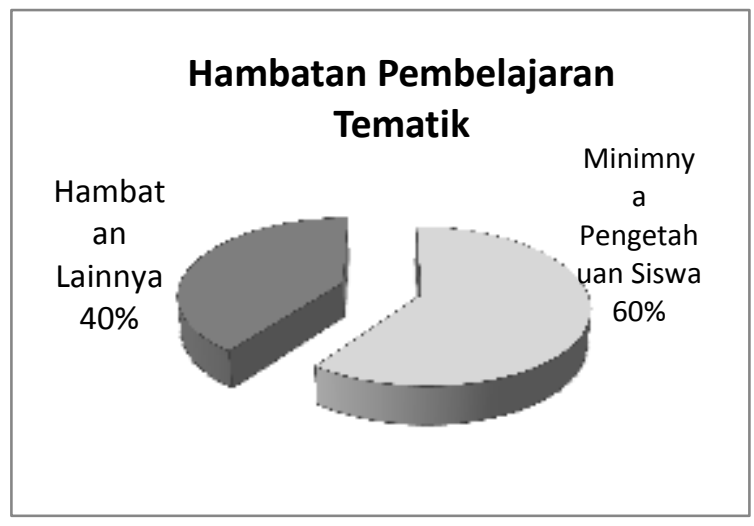

Gambar 4. Diagram Jumlah Guru yang

Menjawab Minimnya Pengetahuan Siswa Sebagai Hambatan Pembelajaran Tematik pada SDN di Gugus III Kecamatan Kalasan.

Salah satu bentuk penyajian data penelitian mengenai cara guru mengatasi hambatan dalam mengimplementasikan pembelajaran tematik di Gugus III Kecamatan Kalasan adalah hasil wawancara dengan guru PW. Terdapat hasil wawancara dengan guru PW dengan kode GTPWW4 mengenai cara guru mengatasi hambatan dalam pembelajaran tematik sebagai berikut: "Caranya ya melalui KKG (Kelompok Kerja Guru), bertukar pengalaman sesama gu$r u$, mengikuti diklat, dan membaca buku tentang pembelajaran tematik."

Secara keseluruhan, upaya guru mengatasi hambatan dalam mengimplementasikan pembelajaran tematik di Gugus III Kecamatan Kalasan dengan menjelaskan pembelajaran tematik kepada orangtua dan siswa, memilih media dan metode yang sesuai, mencari informasi di buku, internet, dan seminar serta berbagi informasi dengan guru tematik yang lain. Berdasarkan hasil reduksi data maka terdapat 4 guru menjawab menjelaskan pembelajaran tematik ke siswa, 4 guru menjawab berbagi informasi dengan guru tematik, 2 guru menjawab memilih metode mengajar yang sesuai, dan 5 guru menjawab dengan upaya lainnya untuk mengatasi hambatan dalam pembelajaran tematik. Upaya guru di Gugus III Kecamatan Kalas- 
an mengatasi hambatan dalam mengimplementasikan pembelajaran tematik digambarkan dalam diagram sebagai berikut.

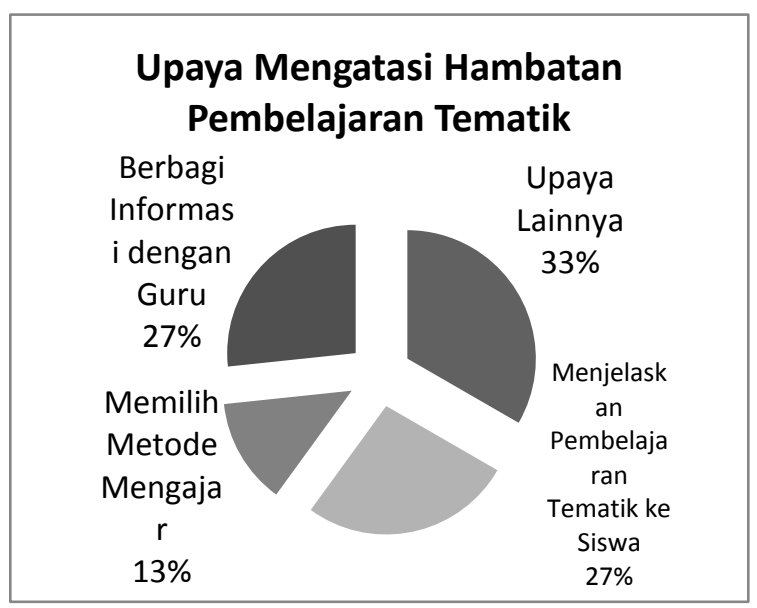

Gambar 5. Diagram Jumlah Guru yang Menjawab Upaya Guru Mengatasi Hambatan Pembelajaran Tematik pada SDN di Gugus III Kecamatan Kalasan.

Deskripsi hasil penelitian ini mengarah pada tugas guru dalam mengimplementasikan pembelajaran tematik pada SDN di Gugus III Kecamatan Kalasan. Tugas guru tersebut dipengaruhi pemahaman, perencanaan, metode mengajar, hambatan, dan upaya mengatasi hambatan dalam pembelajaran tematik. Berdasarkan data-data yang telah disajikan dalam deskripsi hasil penelitian maka rangkuman yang dihasilkan adalah sebagai berikut: (1) Para guru memahami pembelajaran tematik dengan memahami arti pembelajaran tematik dan pemilihan tema. Jumlah guru yang memahami pembelajaran tematik pada SDN di Gugus III Kecamatan Kalasan adalah 13 guru dari total 15 guru. Perhitungan pemahaman guru pada SDN di Gugus III Kecamatan Kalasan yang dihasilkan yaitu $87 \%$ guru dapat memahami pembelajaran tematik. (2) Para guru merencanakan pembelajaran tematik dengan menggunakan silabus dan RPP tematik. Jumlah guru yang merencanakan pembelajaran tematik dengan menggunakan silabus dan RPP tematik pada SDN di Gugus III Kecamatan Kalasan adalah 7 guru dari total 15 guru. Perhitungan perencanaan guru pada SDN di Gugus III Kecamatan Kalasan yang dihasilkan yaitu $47 \%$ guru menggunakan silabus dan RPP tematik. (3) Metode mengajar yang diterapkan para guru dalam implementasi pembelajaran tematik yaitu metode ceramah, kooperatif, dan peragaan. Jumlah guru yang mengimplementasikan pembelajaran tematik di kelas pada SDN di Gugus III Keca- matan Kalasan mayoritas menerapkan metode ceramah. Jumlah guru tersebut adalah 12 guru dari total 15 guru. Perhitungan jumlah metode mengajar yang diterapkan guru pada SDN di Gugus III Kecamatan Kalasan yang dihasilkan yaitu $80 \%$ guru menggunakan metode ceramah. (4) Hambatan yang dihadapi para guru dalam mengimplementasikan pembelajaran tematik SDN di Gugus III Kecamatan Kalasan adalah lingkungan masyarakat yang tidak kondusif, keterbatasan alat peraga, buku, dan sosialisasi dinas serta minimnya pengetahuan siswa, guru, dan orangtua. (5) Upaya guru mengatasi hambatan dalam implementasi pembelajaran tematik SDN di Gugus III Kecamatan Kalasan dengan menjelaskan pembelajaran tematik kepada orangtua dan siswa, memilih media dan metode yang sesuai, mencari informasi di buku, internet, dan seminar serta berbagi informasi dengan guru tematik.

Berdasarkan deskripsi hasil penelitian maka persoalan yang harus dibahas dalam penelitian ini adalah pembelajaran tematik di sekolah dasar, perencanaan administrasi, metode mengajar yang diterapkan, hambatan, dan upaya mengatasi hambatan dalam pembelajaran tematik. Beberapa hal tersebut memengaruhi implementasi pembelajaran tematik pada SDN di Gugus III Kecamatan Kalasan yang terbukti belum dilaksanakan secara maksimal.

Pembelajaran tematik yang dilaksanakan mulai Kurikulum 2013 harus memiliki tema dari semua mata pelajaran termasuk Pendidikan Agama dan Pendidikan Jasmani Olahraga dan kesehatan. Proses pembelajaran semua kompetensi dasar dari semua mata pelajaran terintegrasi dalam berbagai tema (Kementerian Pendidikan dan Kebudayaan, 2013, p.1).

Menteri Pendidikan dan Kebudayaan mengatakan bahwa pelatihan guru secara massal dilakukan pada bulan Juni 2013 untuk memersiapkan Kurikulum 2013 (Nuh, 11 Maret 2013). Ada pelatihan yang diberikan kepada guru sekolah dasar kelas 1 sampai dengan kelas 4 . Pelatihan itu diberikan berkaitan dengan implementasi pembelajaran tematik yang sudah harus dilakukan dari kelas 1 sampai dengan kelas 4.

Wakil Menteri Pendidikan dan Kebudayaan mengatakan bahwa ada buku baru yang berbasis pada kegiatan tematik dan terdapat pelatihan bagi guru yang akan mengajarkan Kurikulum 2013 (Kasim, 21 September 2013). Dalam pelatihan tersebut guru dituntut meminta anak untuk bertanya dan mendorong anak mencari tahu tentang berbagai pengetahuan. 
Kepala Dinas Pendidikan Provinsi Kalimantan Selatan mengungkapkan bahwa ada penggratisan buku-buku sekolah Kurikulum 2013 yang merupakan program pemerintah untuk meringankan beban orangtua siswa (Ngadimun, 4 September 2013). Penggratisan bukubuku tersebut diberikan kepada pihak sekolah yang menyelenggarakan Kurikulum 2013. Bagi pihak sekolah yang belum menyelenggarakan Kurikulum 2013 maka tidak akan diberi bukubuku tersebut karena masih menggunakan KTSP (Kurikulum Tingkat Satuan Pendidikan).

Berdasarkan informasi tentang Kurikulum 2013 tersebut maka implementasi pembelajaran tematik diharapkan akan menjadi lebih mudah dan terkondisikan. Implementasi pembelajaran tersebut terwujud bila pihak sekolah dasar negeri di Gugus III Kecamatan Kalasan sudah ditunjuk oleh dinas pendidikan Kabupaten Sleman untuk melaksanakan Kurikulum 2013. Implementasi pembelajaran tematik bila dilaksanakan mengacu pada Kurikulum 2013 maka sudah ada persiapan dari kesiapan guru tematik dan kesesuaian buku secara tematik. Dari persiapan tersebut diharapkan implementasi pembelajaran tematik tidak terwujudkan dalam pelaksanaan kegiatan pembelajaran secara mata pelajaran atau terpisah baik di dalam kelas maupun luar kelas. Implementasi pembelajaran tematik sebaiknya terlaksana berdasarkan tema yang sudah ditentukan pemerintah khususnya Kementerian Pendidikan dan Kebudayaan. Oleh karena itu, para guru pada SDN di Gugus III Kecamatan Kalasan diharapkan memahami arti pembelajaran tematik.

Dalam Peraturan Menteri Pendidikan Nasional Nomor 16 Tahun 2007 tanggal 4 Mei 2007 disebutkan bahwa guru pada SD/MI harus memiliki kualifikasi akademik pendidikan minimum Diploma Empat (D-IV) atau Sarjana (S1) dalam bidang pendidikan SD/MI (D-IV/S1 PGSD/PGMI) atau psikologi yang diperoleh dari program studi yang terakreditasi. Dari penjelasan tersebut diharapkan guru sekolah dasar memiliki fungsi dan keahlian dalam menangani anak usia sekolah dasar.

"Every teacher needs to understand how children grow and develop to be able to understand how children learn and how best to teach them" (Slavin, 2006, p.29). Slavin berpendapat bahwa setiap guru memerlukan pemahaman bagaimana anak-anak tumbuh dan berkembang untuk mampu memahami bagaimana anak-anak belajar dan bagaimana sebaiknya untuk mengajari mereka. Untuk menjadi guru sekolah dasar maka dibutuhkan pemahaman dalam mendidik dan mengajar anak usia sekolah dasar tentang psikologi yang dimiliki dan tumbuh kembangnya.

Anak usia sekolah dasar yang berusia 7 sampai dengan 11 tahun berada pada tahapan operasional konkret menurut Piaget (2008). Anak usia sekolah dasar sudah mampu untuk berpikir secara benar dan logis. Anak usia sekolah dasar dapat menyusun dan mengurutkan benda berdasarkan ukuran, volume, dan berat. Mereka juga dapat membandingkan dari benda yang sudah diurutkan tersebut jika ditanya mana yang besar dan kecil. Anak perempuan tumbuh lebih pendek daripada anak laki-laki sebelum usia anak perempuan menginjak 9 tahun. Setelah usia anak perempuan menginjak 11 tahun maka anak tersebut tumbuh dan berkembang lebih pesat bila dibandingkan anak lakilaki. Tulang dan otot anak perempuan dan anak laki-laki mulai berkembang pesat pada usia 10 tahun walaupun perkembangan anak laki-laki tertinggal 12 bulan. Kemampuan motorik mereka juga telah berkembang seperti keseimbangan, berlari, melompat, dan melempar. Hal tersebut dapat mendukung kegiatan pembelajaran yang diselingi aktivitas permainan yang dapat dimodifikasi guru sekolah dasar.

Berdasarkan pemahaman tentang anak usia sekolah dasar tersebut maka guru sebaiknya memelajari tentang apa saja yang dimiliki anak didiknya yang berada di sekolah dasar. Dalam pembelajaran tematik, para guru sebaiknya membandingkan kemampuan yang dimiliki anak didiknya dari kelas 1, 2, dan 3. Mereka harus mengetahui perbedaan cara mengajar terutama bila mengajar kelas 1 dibandingkan dengan kelas 3. Menurut Berk. (2012, pp.490-493) terdapat perbedaan perkembangan emosional dan sosial pada anak usia 8 dan 9 tahun dimana usia tersebut berlaku pada anak kelas 2 dan 3. Bila anak pada usia 8 tahun dapat menggunakan strategi memori berupa latihan lalu organisasi maka anak pada usia 9 tahun sudah bisa menggunakan strategi elaborasi selain latihan dan organisasi. Anak pada usia 8 tahun dapat memahami perasaan orang lain sedangkan anak pada usia 9 tahun sudah dapat memilih sahabat setelah ada kepahaman perasaan sesama sahabat. Dari perbandingan sifat anak kelas 2 dan 3 tersebut maka sebaiknya guru tematik sekolah dasar negeri di Gugus III Kecamatan Kalasan menerapkan strategi mengajar yang berbeda demi kesesuaian dan kelancaran kegiatan pembelajaran tematik yang dilakukan di kelas 2 dan 3 . 
Oleh karena itu, para guru pada SDN di Gugus III Kecamatan Kalasan diharapkan memahami pemilihan tema terutama tema yang akan disampaikan dari kelas I, II, dan III. Tema yang disampaikan tersebut sebaiknya ditulis berbeda supaya perbandingan materi pembelajaran tematik yang akan disampaikan untuk kelas I, II, dan III tercantum secara berbeda.

Dalam Peraturan Menteri Pendidikan Nasional Nomor 41 Tahun 2007 tanggal 23 November 2007 disebutkan bahwa perencanaan proses pembelajaran meliputi silabus dan RPP yang memuat identitas mata pelajaran, standar kompetensi (SK), kompetensi dasar (KD), indikator pencapaian kompetensi, tujuan pembelajaran, materi ajar, alokasi waktu, metode pembelajaran, kegiatan pembelajaran, penilaian hasil belajar, dan sumber belajar. Dari penjelasan tersebut dinyatakan betapa pentingnya penggunaan silabus dan RPP untuk dijadikan sebagai perencanaan administrasi dalam pembelajaran tematik.

Dari hasil penelitian implementasi pembelajaran tematik pada SDN di Gugus III Kecamatan Kalasan Kabupaten Sleman Daerah Istimewa Yogyakarta diperoleh adanya guru yang tidak menggunakan silabus dan RPP dalam merencanakan pembelajaran. Hal tersebut tentunya merupakan kejadian yang harus direvisi oleh guru sebagai pengajar maupun perencana pembelajaran.

Pengembangan silabus disusun di bawah supervisi dinas kabupaten/kota yang bertanggung jawab di bidang pendidikan untuk SD dan SMP (BSNP, 2007, p.7). Berdasarkan peraturan tersebut maka silabus yang dibuat dari setiap sekolah dasar itu tertulis berbeda-beda. Guru tematik sekolah dasar negeri di Gugus III Kecamatan Kalasan menulis silabus sesuai permasalahan pembelajaran yang dihadapi sekolah masing-masing.

Guru merancang penggalan RPP untuk setiap pertemuan yang disesuaikan dengan penjadwalan di satuan pendidikan (BSNP, 2007, p.8). Berdasarkan peraturan tersebut maka RPP yang dibuat guru disesuaikan dengan ketersediaan jadwal pelajaran sekolah masing-masing. Sebaiknya RPP yang dibuat guru tematik sekolah dasar negeri di Gugus III Kecamatan Kalasan dicocokkan dengan tema yang akan disampaikan terjadwal pada tanggal yang telah ditentukan. Guru tematik sebaiknya memiliki rancangan tersendiri mengenai jadwal pembelajaran tematik yang disusun sesuai RPP tematik. Guru tematik menyusun jadwal pembelajar- an tematik dengan contoh tema keluarga pada tanggal sekian meskipun jadwal harus diserahkan ke dinas pendidikan Kabupaten Sleman dalam laporan jadwal mata pelajaran terpisah secara sendiri-sendiri.

Berdasarkan hasil reduksi data dari hasil observasi maka terdapat beberapa metode yang diterapkan para guru untuk mengimplementasikan pembelajaran tematik pada SDN di Gugus III Kecamatan Kalasan. Beberapa metode itu adalah metode ceramah, kooperatif, dan peragaan.

Metode ceramah diterapkan guru untuk berdialog dengan siswa untuk mendapatkan respon dari siswa. Guru biasanya mengajak dan menanyai siswa untuk mendapatkan jawaban dari masalah yang diungkapkan. Siswa yang lain juga ditanyai guru dengan variasi pertanyaan yang berbeda tetapi tetap pada masalah yang sama. Hal tersebut sesuai pendapat yang dikemukakan Borich (2007, p.349) bahwa inner speech ultimately leads to a private internal dialogue in the mind of the learner that takes the place of the teacher's prompts and questions and self-guides the learner through similar problems. Borich berpendapat bahwa ceramah mendalam akhirnya memimpin untuk privasi dialog yang bersifat internal dalam pikiran pelajar yang mengambil tempat dari ajakan dan pertanyaan guru dan kemauan pelajar melalui masalah yang sama.

Metode kooperatif diterapkan guru untuk membantu siswa memeroleh manfaat dari kurikulum yang bersifat sikap menghargai dan bekerja sama. Guru biasanya menyuruh para siswa untuk membuat kelompok dalam kegiatan pembelajaran. Siswa dituntut untuk belajar mandiri tanpa bimbingan guru dan bekerja sama dengan temannya. Hal tersebut sesuai pendapat yang dikemukakan Borich (2007, p.371) bahwa cooperative learning is important in helping learners acquire from the curriculum the basic cooperative attitudes and values they need to think independently inside and outside of classroom. Borich berpendapat bahwa pembelajaran kooperatif sangat penting dalam membantu pelajar memperoleh nilai dan sikap dasar kerja sama dari kurikulum secara mandiri di dalam dan di luar ruang kelas.

Metode peragaan diterapkan guru untuk mendorong siswa mendemonstrasikan alat peraga yang disiapkan guru atau dibawa siswa. Guru biasanya menyuruh para siswa untuk maju ke depan kelas untuk menunjukan kinerja dari alat peraga sesuai masalah yang dipelajari pada 
hari itu. Siswa dituntut untuk bisa menjelaskan fungsi dan manfaat dari kegiatan memeragakan yang dipelajarinya. Hal tersebut sesuai pendapat yang dikemukakan Borich (2007, p.239) bahwa modeling is a teaching activity that involves demonstrating to learners what teacher want them to do or think. It can assist leaners to acquire a variety of intellectual and social skills. Borich berpendapat bahwa memeragakan adalah sebuah kegiatan mengajar yang melibatkan demonstrasi dari pelajar yang mana guru menginginkan pelajar untuk melakukannya dan memikirkannya. Peragaan dapat membantu pelajar memperoleh berbagai keterampilan cendekiawan dan kemasyarakatan.

Tanda-tanda pendidikan berkualitas tinggi di sekolah dasar menurut Berk, (2012, p.433) adalah kecukupan ukuran kelas, kelayakan lingkungan fisik, kesesuaian kurikulum, kebutuhan aktivitas harian, adanya interaksi dari guru, adanya evaluasi perkembangan, dan adanya hubungan dari orangtua yang berguna bagi anak usia sekolah dasar untuk belajar di sekolah. Terselenggaranya berbagai hal tersebut dapat menciptakan solusi pembelajaran tematik bagi siswa sekolah dasar untuk berprestasi baik di lingkungan keluarga, sekolah, maupun masyarakat.

Berdasarkan pendapat para guru tematik SDN di Gugus III Kecamatan Kalasan maka terdapat hambatan dan upaya mengatasi hambatan dalam pembelajaran tematik. Hambatan dalam pembelajaran tematik di Gugus III Kecamatan Kalasan adalah lingkungan yang tidak kondusif, keterbatasan alat peraga, buku, dan sosialisasi dinas serta minimnya pengetahuan siswa, guru, dan orangtua. Upaya mengatasi hambatan dalam pembelajaran tematik di $\mathrm{Gu}$ gus III Kecamatan Kalasan dilakukan dengan menjelaskan pembelajaran tematik ke orangtua dan siswa, memilih media dan metode yang sesuai, mencari informasi di buku, internet, dan seminar serta berbagi informasi dengan guru tematik. Guru tematik sekolah dasar negeri di Gugus III Kecamatan Kalasan berpendapat jika hambatan yang dihadapi disebabkan perihal yang berkaitan dengan pembelajaran tematik belum sepenuhnya dirancang oleh pemerintah secara tematik. Hal itu terbukti dengan adanya penyusunan jadwal pelajaran yang harus dibuat secara terpisah tiap mata pelajaran untuk dilaporkan secara tertulis menuju dinas pendidikan di Kabupaten Sleman.

Upaya mengatasi hambatan dalam pembelajaran tematik berupa memilih metode yang sesuai jika dihubungkan dengan pendapat dari Laura Berk seperti kebutuhan aktivitas harian yang berguna bagi siswa SD maka diperlukan adanya pemilihan metode yang berbedabeda dalam aktivitas harian yang dijalani. Guru tematik sekolah dasar negeri di Gugus III Kecamatan Kalasan sebaiknya memberikan aktivitas pembelajaran yang menantang. Dalam aktivitas itu, terdapat penggunaan metode kooperatif, kerja kelompok, dan kerja individu yang harus dilakukan siswa SD yang berbeda dari hari ke hari berikutnya. Selain itu, guru juga harus memilih metode mengajar seperti ceramah, peragaan, dan bermain peran untuk diterapkan secara berbeda-beda dari hari ke hari berikutnya. Minimnya pengetahuan siswa SD tentang pembelajaran tematik akan terisi dan bertambah jika para guru tematik sekolah dasar negeri di Gugus III Kecamatan Kalasan mengarahkan para siswa untuk mencari informasi tentang pembelajaran tematik di internet dengan menggunakan komputer.

Berdasarkan pendapat dari Laura Berk mengenai kelayakan lingkungan fisik bagi anak usia sekolah dasar maka upaya mengatasi hambatan dalam pembelajaran tematik berupa lingkungan yang tidak kondusif yaitu diusahakan adanya perbaikan pengadaan pusat-pusat aktivitas yang bermanfaat bagi siswa SD baik di lingkungan masyarakat maupun lingkungan sekolah. Siswa SD memiliki ruang untuk melakukan aktivitas membaca, menulis, bermain matematika atau bahasa, mengeksplorasi sains, dan menggunakan komputer. Oleh karena itu, perlu diselenggarakan bimbingan belajar di lingkungan masyarakat baik itu bersifat swadaya maupun berbayar demi kebutuhan anak untuk belajar.

Pelaksanaan lokakarya untuk meningkatkan kemampuan guru dalam menerapkan atau melaksanakan pembelajaran dapat dilakukan oleh sekelompok guru yang memiliki maksud yang sama (Sumiati \& Asra, 2009, p.247). Lokakarya adalah pertemuan antara para ahli (pakar) untuk membahas masalah praktis atau yang bersangkutan dengan pelaksanaan dalam bidang keahliannya. Para guru tematik sekolah dasar negeri di Gugus III Kecamatan Kalasan dapat melakukan lokakarya atau seminar dengan mengundang para ahli di bidang pembelajaran tematik untuk menemukan upaya mengatasi hambatan dalam mengimplementasikan pembelajaran tematik. Guru diharapkan mampu mencari informasi di buku, internet, dan seminar supaya guru memiliki inovasi untuk meng- 
atasi keterbatasan dalam mengajar pembelajaran tematik. Selain itu, guru dapat berbagi informasi dengan guru tematik lainnya untuk menambah pengetahuan mereka. Hal tersebut dapat dilakukan secara pertemuan mandiri (bertemu secara langsung) maupun secara pertemuan resmi (bertemu dalam kegiatan formal seperti pertemuan para guru dalam satu gugus).

\section{Simpulan dan Saran}

Simpulan

Berdasarkan hasil penelitian dan pembahasan maka dapat dikemukakan kesimpulan implementasi pembelajaran tematik pada SDN di Gugus III Kecamatan Kalasan sebagai berikut: (1) Guru sudah memahami pembelajaran tematik, tetapi masih ada 2 guru yang belum memahaminya; (2) Guru sudah merencanakan pembelajaran tematik dengan menggunakan silabus dan RPP yang memiliki tema, tetapi masih ada 8 guru yang tidak menggunakannya; (3) Metode mengajar yang diterapkan para guru dalam implementasi pembelajaran tematik yaitu metode ceramah, kooperatif, dan peragaan; (4) Hambatan yang dihadapi adalah: (a) Minimnya pengetahuan orangtua dan siswa. (b) Lingkungan masyarakat yang tidak kondusif. (c) Keterbatasan alat peraga, buku, dan sosialisasi dinas. (d) Minimnya pengetahuan guru; (5) Upaya guru mengatasi hambatan dengan: (a) Menjelaskan pembelajaran tematik kepada orangtua dan memilih media dan metode yang sesuai untuk siswa. (b) Menyelenggarakan bimbingan belajar di lingkungan masyarakat. (c) Mencari informasi di buku, internet, dan seminar supaya guru memiliki inovasi untuk mengatasi keterbatasan pembelajaran tematik. (d) Berbagi informasi dengan guru tematik yang lain untuk menambah pengetahuan.

Saran

Berdasarkan hasil kesimpulan penelitian maka dapat dikemukakan saran seperti berikut: (1) Guru SDN kelas 1, 2, dan 3 Gugus III Kecamatan Kalasan harus selalu berusaha belajar dan meningkatkan pemahaman tentang implementasi pembelajaran tematik dengan belajar dari berbagai sumber dan referensi. (2) Pemerintah Kabupaten Sleman melalui Dinas Pendidikan harus lebih giat lagi dalam melakukan sosialisasi, seminar, dan pelatihan tentang pembelajaran tematik, terutama di wilayah Gugus III Kecamatan Kalasan. (3) Pemerintah Kabupaten Sleman melalui Dinas Pendidikan harus bekerja sama dengan pihak perguruan tinggi negeri/swasta untuk menyeleksi seminar atau pelatihan bagi guru tematik di sekolah dasar dengan menghadirkan pakar/ahli profesor yang berkompeten di bidang pembelajaran tematik baik yang berasal dari dalam negeri maupun luar negeri.

\section{Daftar Pustaka}

Anonim. (1990). Peraturan Pemerintah Republik Indonesia Nomor 28 Tahun 1990 tentang Pendidikan Dasar.

Badan Standar Nasional Pendidikan. (2007). Standar proses untuk satuan pendidikan dasar dan menengah. Jakarta: BSNP.

Berk, L.E. (2012). Development through the lifespan. (Terjemahan Daryatno). Boston: Pearson Education Inc. (Buku asli diterbitkan tahun 2010).

Borich, G.D. (2007). Effective teaching methods: research-based practice. New Jersey: Pearson Prentice Hall.

Depdiknas. (2003). Undang-undang Republik Indonesia No. 20 Tahun 2003 tentang Sistem Pendidikan Nasional.

Depdiknas. (2005). Peraturan Pemerintah Republik Indonesia no. 19 Tahun 2005 tentang Standar Nasional Pendidikan.

Depdiknas. (2007). Peraturan Menteri Pendidikan Nasional No. 16 Tahun 2007 tentang Standar Kualifikasi dan Kompetensi Guru.

Depdiknas. (2007). Peraturan Menteri Pendidikan Nasional No. 41 Tahun 2007 tentang Standar Proses.

Depdiknas. (2011). Wajib belajar. Diambil tanggal 12 Februari 2013, dari http:// id.wikipedia.org/wiki/Wajib_belajar.ht $\mathrm{ml}$

Kemdikbud. (2013). Kurikulum 2013: Kompetensi Dasar SD/MI. Jakarta: Kemdikbud.

Kasim, M. (21 September 2013). Kurikulum 2013 bawa tiga perubahan besar. 
Diambil tanggal 12 Oktober 2013, dari http://suaramerdeka.com/v1/index.php/r ead/news/2013/09/21/172829.html.

Miles, M.B. \& Huberman, A.M. (1994). Qualitative data analysis: An expanded source book. London: Sage Publications.

Ngadimun. (4 September 2013). Pemerintah gratiskan buku pelajaran Kurikulum 2013. Diambil tanggal 12 Oktober 2013, dari http://www.antaranews.com/ berita/393991/pemerintah-gratiskanbuku-pelajaran-kurikulum-2013.html.

Nuh, M. (4 Desember 2012). Mendikbud: 2013, wajib belajar 12 tahun \& kurikulum baru diterapkan. Diambil tanggal 13 November 2013, dari http://news. detik.com/read/2012/12/04/150638/210 9092/10/mendikbud-2013-wajibbelajar-12-tahun-kurikulum-baruditerapkan. html.
Nuh, M. (11 Maret 2013). Menteri Nuh: kurikulum 2013 siap dilaksanakan. Diambil tanggal 12 Oktober 2013, dari http://www.tempo.co/read/news/2013/0 3/11/079466309/Menteri-NuhKurikulum-2013-SiapDilaksanakan.html.

Piaget. (2008). Piaget's theory of cognitive development. Diambil tanggal 12 Oktober 2013, dari http://en.wikipedia. org/wiki/Piaget\%27s_theory_of_cogniti ve_development.html.

Slavin, R.E. (2006). Educational psychology: Theory and practice. Eight Edition. Boston: Pearson educational, Inc.

Sumiati \& Asra. (2009). Metode pembelajaran. Bandung: CV Wacana Prima.

Unesco. (2013). Education for all. Diambil tanggal 13 Juli 2013, dari http://en.wikipedia.org/wiki/Education_ For_All.html.. 